\title{
THE FINANCIAL SITUATION AS A STIMULANT OF THE COMPETITIVE POSITION OF RURAL COMMUNES IN THE ŚWIĘTOKRZYSKIE VOIVODESHIP
}

\author{
Andrzej Pawlik ${ }^{1}$, Urszula Karpinska²
}

\begin{abstract}
Market conditions force local governments to take actions directed to the development and improvement of competitiveness. The efficiency of municipalities is determined by the efficiency and dynamics of development of the entire economy. The financial situation is a component of the competitiveness and responsibility of local authorities for the socio-economic development of the commune. The aim of the article is to analyse the spatial disproportions of the financial situation of rural communes in relation to their competitiveness using the TOPSIS synthetic measure. The analysis was conducted in a system of 69 rural communes of the Świętokrzyskie province. To assess the financial situation, the following were used: own income, local taxes and fees, income from PIT and $\mathrm{CIT}$, operating surplus, transfer income and EU funds, property (investment) expenses, as well as interest and debt expenses. The conducted research showed that in the analysed period of 2007-2017 communes were characterized by stable diversification of financial situation and competitiveness.
\end{abstract}

Key words: financial situation, competitiveness, rural communes, synthetic measure.

JEL Classification: C38, H71, H76, B41, R10, P25

\section{Introduction}

Identifying the level of competitiveness on a local scale becomes difficult because the commune functions and develops as an integral part of a larger whole, i.e. region or country. It uses goods and services from other areas and produces and delivers its products to the environment. Communes are service entities whose purpose is to meet the needs of residents. Their source of income is mainly local taxes and fees, as well as transfers from the state budget. Market conditions force local governments to undertake development-oriented activities (improving competitiveness). The efficiency of municipalities is determined by the efficiency and dynamics of development of the entire economy (Standar, 2017).

The financial situation is understood as the ability to finance services using the accumulated income in the given socio-economic and institutional conditions and to pay liabilities in a given period. It is a component of the competitiveness and responsibility of local authorities for the socio-economic development of the commune (Majchrzak, 2012). It also concerns the level of satisfying the current needs of local communities and undertaking development activities of communes (Satoła, 2015). The financial situation of local government is therefore directly related to the access

Corresponding author:

${ }^{1}$ Jan Kochanowski University in Kielce, Poland.

E-mail: andrzejp1@vp.pl

ORCID: https://orcid.org/0000-0003-2319-6707

${ }^{2}$ Bank Spółdzielczy in Kielce, Poland. to sources of financial supply and largely conditioned by the possession by the local government unit (LGU) of stable and adequate sources of income (GlowickaWołoszyn, Wysocki, 2016). As indicated by M. Stanny and W. Strzelczyk, the financial situation is the ability to regulate financial obligations while ensuring continuity in the implementation of statutory tasks of the commune and improving the living conditions of the residents (Stanny, Strzelczyk, 2018).

Assessment of the financial situation of municipalities allows determining not only the efficiency of these units, i.e. the ability to meet their obligations, but also the possibility of raising the quality standard of services they provide to local communities (Dziekański, 2014).

Competitiveness of municipalities is the ability to adapt positive trends emerging in the environment, creating internal and external benefits for them, e.g. the development of entrepreneurship or the creation of local development (Marciniuk-Kluska, 2009). It is a complex phenomenon and difficult to unambiguously and objectively evaluate. It depends on both endogenous and exogenous factors of economic development. The process of the unit's operation (increasing competitiveness) takes place in a space that is completely filled by the internal and external environment, including natural and economic. 
The environment and the economy form a network of interconnectedness and, acting for the benefit of the community, are interdependent and should be considered together (Zakrzewska-Póltorak, 2011).

\section{Purpose, method, scope of the study}

The aim of the article is to analyse the spatial disproportions of the financial situation of rural communes in relation to their competitiveness using the TOPSIS synthetic measure. The analysis was made in the system of 69 rural communes of the Świętokrzyskie province. As source material, data from the Regional Accounting Chamber (Kielce branch) and Local Database of the Central Statistical Office for 2007, 2014, and 2017 were used. In the context of competitiveness assessment in rural communes, the following were used: changes in the population, migration balance, unemployment rate, persons employed in communes, entities entered in the register, natural persons conducting the business activity, housing resources, and those using the plumbing and sewage installation. To assess the financial situation, the following were used: own income, local taxes and fees, income from PIT and CIT, operating surplus, transfer income and EU funds, property (investment) expenses, as well as interest and debt expenses. The analysis preferred variables with relative values (Pawlik, 2012; Dziekański, Pawlik, 2019). Statistical features are divided into 4 dimensions: income, expenses, taxation, and debt.

In order to determine the measure of synthetic development, the following procedure was performed:

1. From the set of selected variables, those characterized by low spatial variability and high correlation of variables were removed (according to the inverted matrix method) (Wysocki, 2010; Malina, 2004).

2. Variables that were subjected to the procedure were selected zeroed unitarisation using the following formulas:

$$
\begin{aligned}
& \text { for stimulants } z_{i j}=\frac{\mathrm{x}_{i j}-\min _{i} \mathrm{x}_{i j}}{\max _{i} \mathrm{x}_{i j}-\min _{i} x_{i j}} \text {, if } x_{i} \in S \\
& \text { for destimulants } z_{i j}=\frac{\max _{i} \mathrm{x}_{i j}-\mathrm{x}_{i j}}{\max _{i} x_{i j}-\min _{i} \mathrm{x}_{i j}} \text {, if } x_{i} \in D
\end{aligned}
$$

where: $S$ - stimulant, $D$ - determinant; $i=1,2 \ldots n$; $j=1,2 \ldots n, x_{i j}$ - means the value of the $j$-t feature for the examined unit, max - the maximum value of the $j$-t feature, min - the minimum value of the $j$-t feature (Wysocki, Lira, 2005; Kukuła, 2000; Młodak, 2006; Dziekański, 2017).

3. Using the distance of each object element from the pattern and anti-pattern (from the pattern $z_{j}^{+}=(1,1, \ldots, 1)$ and anti-announcer development $z_{j}^{-}=(0,0, \ldots, 0)$, (Walesiak, 2011). Euclidean distances were calculated according to the formula:

$$
d_{i}^{+}=\sqrt{\frac{1}{n} \sum_{j=1}^{m}\left(z_{i j}-z_{j}^{+}\right)^{2}}
$$

$$
d_{i}^{-}=\sqrt{\frac{1}{n} \sum_{j=1}^{m}\left(z_{i j}-z_{j}^{-}\right)^{2}}
$$

where $n$ - the number of variables making up the pattern or anti-pattern, $z_{j}$ - denotes the unified value of the characteristic for the unit being tested (Wysocki, 2010; Zalewski, 2012).

4. The values of the synthetic feature were calculated according to the TOPSIS method for individual objects based on the formula:

$$
q_{i}=\frac{d_{i}^{-}}{d_{i}^{-}+d_{i}^{+}}, \text {when } 0 \leq q_{i} \leq 1, i=1,2, \ldots, n ; \mathrm{qi} \in[0 ; 1] \text {; }
$$

Whereby: $d_{i}^{-}$means the distance from the object from the anti-template (from 0$), d_{i}^{+}$means the distance of the object from the template (from 1 ). TOPSIS method is based on the calculation of the Euclidean distances of the assessed object from both the pattern and the developmental anti-pattern, which distinguishes it from the Hellwig's method, which only takes into account the distance from the development pattern. Higher values of the qi meter $\in[0,1]$ indicate a more favourable financial position of the audited entity (Hwang, Yoon, 1981; Łuczak, Wysocki, 2012).

5. The studied area of rural communes in the Świętokrzyskie voivodship was divided into 4 quartile groups. The size of the indicator in the first group means a better unit, in the last one the weakest. The mutual compliance of the results obtained was also verified based on the correlation coefficient. A scatter chart with an adjustment line for synthetic measures is also presented (Dziekański, 2016; Dziekański, Wyszkowski, 2018; Prus, Dziekański, 2019).

\section{Financial situation and the level of competitiveness}

Satisfying the collective needs of the commune's inhabitants or increasing its investment attractiveness depends to a large extent on their own and foreign income, as well as the ability to use it effectively. Therefore, it is important that systematic analyses of the management of these funds are made by the unit's bodies. The efficiency and transparency of financial management processes are conditioned by clearly formulated goals and properly run financial management (Dylewski, Filipiak, Szewczyk, 2004).

It is worth noting that from the analyses conducted by Churski and co-authors (2013) and Stanny (2013) it follows that local finance is the most important development factor. Hendrick points out that the financial situation cannot be described in onedimensional space (one indicator).

The value of a commune's financial standing can be used as a tool to study how various factors affect it and what its financial policy looks like. Income, expenses, taxation, and debt are a complex and multi-dimensional concept with different time frames. Related elements must be analysed 
and evaluated together (Hendrick, 2004). Douglas and Gaddie (2002) relate their financial situation to the ability to meet their financial obligations in a timely manner and to ensure continuity in providing services to the local community. Another index developing the measure of assessing the financial situation of municipalities was presented by Mercer and Gilbert (1996), who created a comprehensive index of financial condition based on indicators grouped into four dimensions: income, expenses, taxation, and debt of the economy.

The financial situation of communes is a component of competitiveness and responsibility of local authorities for the development of the commune and meeting the needs of its inhabitants. The financial situation of municipalities is primarily determined by the size and appropriate matching over time of income and expenditure. It consists of, among others: the level of income, financial independence, the amount of investment expenditure, the ability to raise extrabudgetary funds, the financial result (Ossowska, Ziemińska, 2010). External determinants, e.g. the level of economic growth, unemployment, inflation rate, the socio-economic situation of neighbouring areas, are not directly influenced by local authorities. In turn, internal conditions of the commune's financial situation can be shaped to some extent by its authorities, e.g. by using location rent, activating human resources, creating conditions for increasing the economic activity of residents, increasing management efficiency, using natural resources and natural assets (Ślusarz, 2005).

A. Klasik and F. Kuźnik define regional development as the sustainable growth of three elements: the economic potential of regions, their competitive strength, and the level and quality of life of residents. The essence of regional development is to ensure functionality and it occurs in three dimensions: economic, social, and territorial. This increases the competitiveness of the area, defined as its advantage or distance in relation to other regions forming a strategic group together from the point of view of the distinguished types of strategic activities. The competitiveness of municipalities is their lasting ability to meet other competitors in their various competitive systems (Klasik, Kuźnik, 2001). It means the ability to guarantee a social and economic environment supporting economic activity and the process of raising the overall level of productivity and innovation using internal and external human, financial, and material resources. It is identified with its main determinants: the level of economic activity, labour market and human capital, spatial and ICT accessibility, and innovation (Żbikowski, 2015).

\section{A measure of the financial standing of communes in the Świętokrzyskie Province}

The Świętokrzyskie Voivodship is an industrial and agricultural region with a high concentration of industry sectors related to the production and processing of metals, mining and processing of mineral resources, and the production of foodstuffs. The metallurgy, metal, machinery, building materials and food industries dominate in the Świętokrzyskie region. The economy of the Swiętokrzyskie region is based on the mining industry in the field of building materials (limestone, dolomite, marl, gypsum, sandstone). The agricultural south is the base for the production of organic food (Jóźwiak, Jóźwiak, Strzyż, 2010; Profil gospodarczy województwa świętokrzyskiego; Raport o sytuacji społeczno-gospodarczej..., 2018).

Table 1 summarizes the values of synthetic measures of the financial situation and competitiveness in 2007, 2014, 2017 in subsequent quartile groups. Group A includes communes with the highest values of TOPSIS indicators, i.e. units in the best financial situation and the highest level of competitiveness, in Group D - the weakest units, due to each of the analysed indicators.

The value of the synthetic measure allowed dividing the communes of the Świętokrzyskie Province into 4 groups. Small groups in time and space can be observed between the groups. In 2017, the synthetic measure of the financial situation ranged from 0.30 (Bliżyn, the weakest unit; Skarżyski poviat) to 0.51 (Sitkówka-Nowiny, the best unit; Kielce poviat) and in 2007 from 0.31 (Pierzchnica, Kielce poviat) to 0.47 (Sitkówka-Nowiny, Kielce poviat). The synthetic measure of competitiveness in 2017 took values from 0.37 (Moskorzew, Włoszczowski poviat) to 0.51 (Masłów, Kielce poviat; Sitkówka-Nowiny, Kielce poviat). In 2007, respectively, from 0.35 (Bejsce, Kazimierz poviat) to 0.48 (Sitkówka-Nowiny, Kielce poviat; Miedziana Góra, Kielce poviat). The best units in the studied area are located in the central part of the province, in the area of impact of Kielce (the capital of the region). The best units of Sitkówka-Nowiny, Masłów, Szydłów, Solec-Zdrój (due to the financial situation) and Masłów, Sitkówka-Nowiny, Strawczyn, Łagów (due to competitiveness) have a developed industrial function (mining and processing of mineral raw materials, production groceries) and tourism.

The financial situation of municipalities is correlated with the level of competitiveness and translates into disproportions in the scope of the ability to meet local needs. Determinants of financial standing and competitiveness may be shaped by the area (e.g. location and size of local government units, available resources and natural values, investment attractiveness) and may also be independent of it (e.g. economic fluctuations in the country and in the world, the state of public finances, scope of income and expenditure authority of local government units) (Dziekański, 2014).

The box graph indicates whether the data is symmetrical and how the data is distributed, whether there are outliers in the data set. It also indicates the dispersion of data (the longer the graph, the more spread the data means, that they can take different values) (Euczak, 2007). 
Table 1

Classification of rural communes in the Świętokrzyskie province according to a synthetic measure, financial situation, and competitiveness for 2007, 2014, 2017

\begin{tabular}{|c|c|c|c|c|c|c|}
\hline & \multicolumn{3}{|c|}{ TOPSIS financial situation } & \multicolumn{3}{|c|}{ TOPSIS competitiveness } \\
\hline & 2007 & 2014 & 2017 & 2007 & 2014 & 2017 \\
\hline A & $\begin{array}{l}\text { Sitkówka-Nowiny } \\
0.47 \\
\text { Smyków } 0.45 \\
\text { Wojciechowice } 0.41 \\
\text { Zagnańsk } 0.38\end{array}$ & $\begin{array}{l}\text { Sitkówka-Nowiny } \\
0.46 \\
\text { Tuczępy } 0.43 \\
\text { Oleśnica } 0.41 \\
\text { Szydłów } 0.40\end{array}$ & $\begin{array}{l}\text { Sitkówka-Nowiny } \\
0.51 \\
\text { Masłów } 0.39 \\
\text { Szydłów } 0.39 \\
\text { Solec-Zdrój } 0.37\end{array}$ & $\begin{array}{l}\text { Miedziana Góra } \\
0.48 \\
\text { Sitkówka-Nowiny } \\
0.48 \\
\text { Krasocin } 0.47 \\
\text { Górno } 0.43\end{array}$ & $\begin{array}{l}\text { Miedziana Góra } \\
0.51 \\
\text { Strawczyn } 0.51 \\
\text { Sitkówka-Nowiny } \\
0.51 \\
\text { Radoszyce } 0.44\end{array}$ & $\begin{array}{l}\text { Masłów } 0.51 \\
\text { Sitkówka-Nowiny } \\
0.51 \\
\text { Strawczyn } 0.51 \\
\text { Łagów } 0.45\end{array}$ \\
\hline B & $\begin{array}{l}\text { Baćkowice } 0.37 \\
\text { Baftów0.37 } \\
\text { Bejsce } 0.37 \\
\text { Sadowie } 0.37\end{array}$ & $\begin{array}{l}\text { Bogoria } 0.39 \\
\text { Kije } 0.39 \\
\text { Masłów (2) } 0.39 \\
\text { Solec-Zdrój (2) } 0.36\end{array}$ & \begin{tabular}{|l} 
Ruda Maleniecka \\
0.36 \\
Sobków 0.36 \\
Waśniów 0.36 \\
Zagnańsk 0.35 \\
\end{tabular} & $\begin{array}{l}\text { Łagów } 0.42 \\
\text { Łoniów } 0.42 \\
\text { Oleśnica } 0.42 \\
\text { Szydłów } 0.41\end{array}$ & $\begin{array}{l}\text { Łączna } 0.43 \\
\text { Nowa Słupia } 0.43 \\
\text { Szydłów } 0.43 \\
\text { Bałtów } 0.42\end{array}$ & $\begin{array}{l}\text { Nowa Słupia } 0.44 \\
\text { Rytwiany } 0.44 \\
\text { Sobków } 0.44 \\
\text { Pacanów } 0.42\end{array}$ \\
\hline $\mathrm{C}$ & $\begin{array}{l}\text { Bieliny } 0.36 \\
\text { Czarnocin } 0.36 \\
\text { Gnojno } 0.36 \\
\text { Wodzisław } 0.36\end{array}$ & $\begin{array}{l}\text { Dwikozy } 0.35 \\
\text { Łoniów } 0.35 \\
\text { Moskorzew } 0.35 \\
\text { Zagnańsk } 0.34\end{array}$ & $\begin{array}{l}\text { Bałtów } 0.34 \\
\text { Nowy Korczyn } 0.34 \\
\text { Raków } 0.34 \\
\text { Rytwiany } 0.34\end{array}$ & \begin{tabular}{|l} 
Kluczewsko 0.4 \\
Mirzec 0.4 \\
Opatowiec 0.4 \\
Nowa Słupia 0.39 \\
\end{tabular} & $\begin{array}{l}\text { Dwikozy } 0.41 \\
\text { Iwaniska } 0.41 \\
\text { Obrazów } 0.41 \\
\text { Klimontów } 0.4 \\
\end{array}$ & $\begin{array}{l}\text { Baćkowice } 0.41 \\
\text { Iwaniska } 0.41 \\
\text { Klimontów } 0.41 \\
\text { Waśniów } 0.41 \\
\end{array}$ \\
\hline $\mathrm{D}$ & $\begin{array}{l}\text { Brody } 0.35 \\
\text { Dwikozy } 0.35 \\
\text { Klimontów } 0.35 \\
\text { Pierzchnica } 0.31 \\
\end{array}$ & $\begin{array}{l}\text { Bieliny } 0.33 \\
\text { Górno } 0.33 \\
\text { Piekoszów } 0.33 \\
\text { Iwaniska } 0.3 \backslash \\
\end{array}$ & \begin{tabular}{|l} 
Bieliny 0.33 \\
Dwikozy 0.33 \\
Iwaniska 0.33 \\
Bliżyn 0.3 \\
\end{tabular} & \begin{tabular}{|l} 
Obrazów 0.38 \\
Sady 0.38 \\
Waśniów 0.38 \\
Bejsce 0.35 \\
\end{tabular} & $\begin{array}{l}\text { Baćkowice } 0.39 \\
\text { Michałów } 0.39 \\
\text { Bejsce } 0.38 \\
\text { Nagłowice } 0.37 \\
\end{array}$ & $\begin{array}{l}\text { Dwikozy } 0.4 \\
\text { Imielno } 0.4 \\
\text { Michałów } 0.4 \\
\text { Moskorzew } 0.37 \\
\end{array}$ \\
\hline
\end{tabular}

Sorted by quartile value for the given surveyed year; the table shows the 3 best and the weakest units in the group; the size of the indicator in group A means a better unit, in D - the weakest

Source: own study based on data from RIO o / Kielce and BDL CSO

As presented in Figure 1, the diversity of the measure of synthetic financial situation is smaller in relation to competitiveness. The outliers in terms of financial standing are Sitkówka Nowiny (with an industrial function developed), Smyków and Pierzchnica (in 2007).

Measures of spatial differentiation (Table 2) indicate the constant dispersion of municipalities in terms of the financial situation. The standard deviation provides us with the necessary knowledge about whether the results in a given group are similar or different. In 2017, compared to 2007, the results show stability according to the standard deviation for both the financial situation (0.36-0.37) and competitiveness (0.03-0.03). The difference in the value of the 0.21-0.16 range (2017-2007) in the aspect of the financial situation indicates a greater differentiation than in the aspect of competitiveness $0.14-0.13$. The lack of differentiation is also indicated by the classic coefficient of variation, which in the analysed period was 0.08-0.06 (2017$2007)$ and competitiveness $(0.08-0.07)$ respectively.
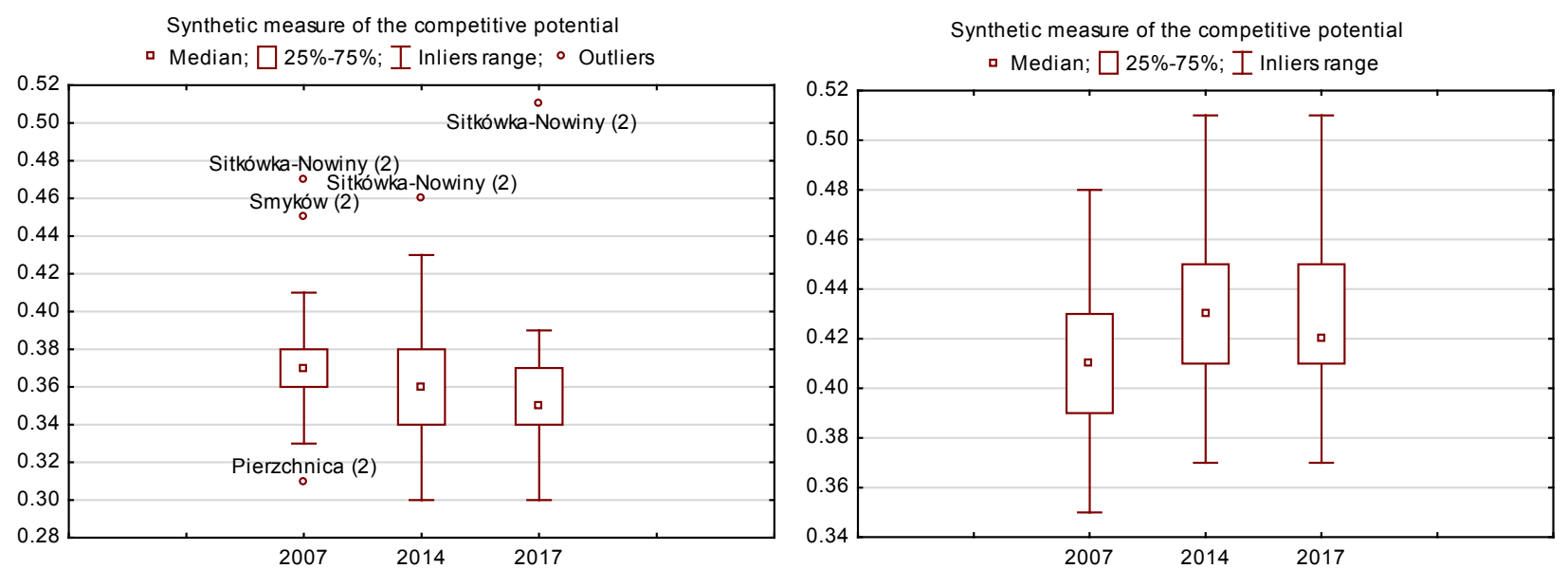

Figure 1. Graph of dispersion of rural communes in the Świętokrzyskie voivodship in the aspect of financial situation and development in 2007, 2014, 2017

Source: own study based on data from RIO o / Kielce and BDL CSO 
Table 2

Differentiation of synthetic measure - financial situation and competitiveness

\begin{tabular}{|c|c|c|c|c|c|c|}
\hline & \multicolumn{3}{|c|}{ TOPSIS financial situation } & \multicolumn{3}{|c|}{ TOPSIS competitiveness } \\
\hline & 2007 & 2010 & 2017 & 2007 & 2010 & 2017 \\
\hline average & 0.37 & 0.36 & 0.36 & 0.41 & 0.42 & 0.43 \\
\hline median & 0.37 & 0.36 & 0.35 & 0.41 & 0.42 & 0.42 \\
\hline standard deviation & 0.02 & 0.04 & 0.03 & 0.03 & 0.03 & 0.03 \\
\hline quarter (quartile) deviation & 0.37 & 0.37 & 0.36 & 0.41 & 0.42 & 0.43 \\
\hline classic coefficient of variation & 0.06 & 0.11 & 0.08 & 0.07 & 0.08 & 0.08 \\
\hline positional coefficient of variation & 1.00 & 1.03 & 1.01 & 1.00 & 1.00 & 1.02 \\
\hline $\min$ & 0.31 & 0.28 & 0.30 & 0.35 & 0.36 & 0.37 \\
\hline $\max$ & 0.47 & 0.49 & 0.51 & 0.48 & 0.51 & 0.51 \\
\hline range & 0.16 & 0.21 & 0.21 & 0.13 & 0.15 & 0.14 \\
\hline quartile 1 & 0.36 & 0.34 & 0.34 & 0.39 & 0.40 & 0.41 \\
\hline quartile 2 & 0.37 & 0.36 & 0.35 & 0.41 & 0.42 & 0.42 \\
\hline quartile 3 & 0.38 & 0.40 & 0.37 & 0.43 & 0.44 & 0.45 \\
\hline quartile range & 0.02 & 0.06 & 0.03 & 0.04 & 0.04 & 0.04 \\
\hline skewness & 1.58 & 0.28 & 2.19 & 0.41 & 0.67 & 0.72 \\
\hline measure of concentration (kurtosis) & 6.43 & 0.26 & 11.35 & 0.10 & 0.41 & 0.07 \\
\hline
\end{tabular}

Source: own study based on data from RIO o / Kielce and BDL CSO

Pearson's correlation coefficient between the value of the measure of the synthetic financial situation in 2007 in relation to 2014 was 0.517 and in 2014 to $2017-0.654$. For the measure of synthetic competitiveness, it was 0.871 and 0.928 , respectively. In both cases, we are dealing with a convergence process. It can be assumed that the spatial diversity of the studied area was quite stable, and the units reacted similarly to changes in the economy. Units distinguished in both studied areas are: Sitkówka-Nowiny, Masłów, Strawczyn, and Miedziana Góra characterized by developed industrial function. They provide facilities for the capital of the Kielce region. Located in the Kielce poviat, whose economy is characterized by the mining and processing industry of mineral raw materials and the production of foodstuffs (Figure 2).

The correlation coefficients presented in Table 3 show that the greatest impact on the level of the financial situation of rural communes in the Świętokrzyskie voivodship had: own revenues, from local taxes and fees, transfer, operating surplus and property (investment) and current expenses. In the analysed period, the level of competitiveness was influenced by: income from PIT and CIT and also transfer, as well as the number of entities entered into the register and the number of natural persons conducting business activity. The diversity of the financial situation of rural communes and their competitiveness was stable in the analysed years of 2007, 2014, and 2017.

The values of Pearson's linear correlation coefficients (Table 3) confirm the existence of positive and negative correlations between the indicated elements. The analysed variables can be taken into account when modelling the effectiveness of municipalities.

Table 3

Correlation of a measure of synthetic financial situation and competitiveness with their determinants

\begin{tabular}{|l|c|c|}
\hline & TOPSIS financial situation & TOPSIS competitiveness \\
\hline TOPSIS competitiveness & 0.125 & 1.000 \\
\hline Own income & 0631 & 0.097 \\
\hline Income from taxes and local fees & 0.584 & 0208 \\
\hline Income from PIT and CIT & 0.071 & 0.547 \\
\hline Transfer income & $-0,533$ & $-0,359$ \\
\hline Operating surplus & 0.505 & 0.149 \\
\hline Property (investment) expenses & 0.454 & 0.094 \\
\hline Current expenditure & 0.454 & $-0,098$ \\
\hline Registered unemployed persons & $-0,116$ & 0.298 \\
\hline Number of persons employed & 0.039 & 0.351 \\
\hline Entities entered in the register & 0.133 & 0729 \\
\hline Self-employed persons & 0.087 & 0740 \\
\hline
\end{tabular}

Linear correlation coefficients for observations from sample 1-207; Critical value (at a two-sided 5\% critical area) $=0.1364$ for $n=207$

Source: own study based on data from RIO o / Kielce and BDL CSO 

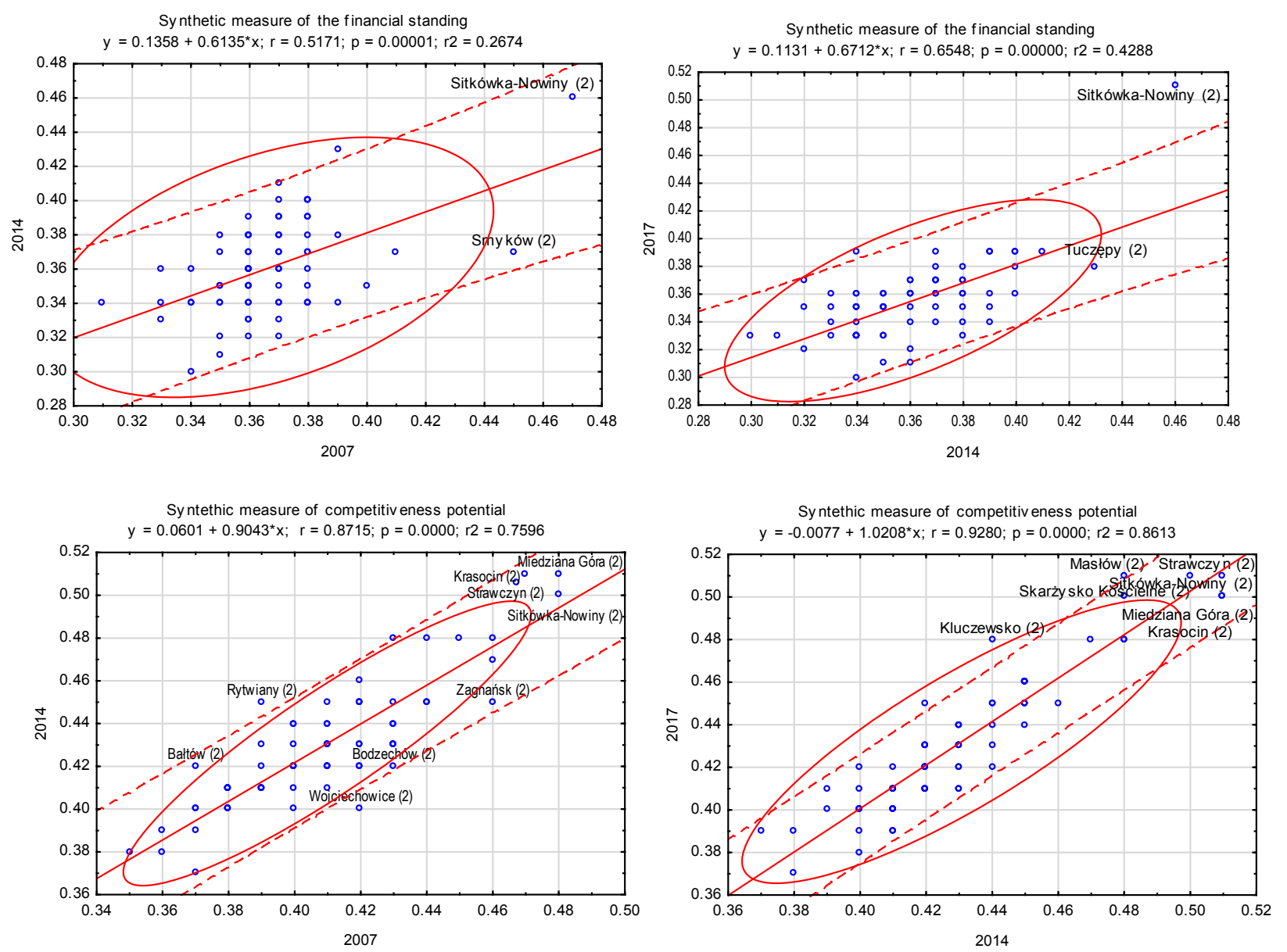

Figure 2. Scatter chart of synthetic measure - financial situation and competitiveness from 2014 to 2017

Source: own study based on data from RIO o / Kielce and BDL CSO

Regression analysis allows you to create a linear model that lets you check how variables affect a dependent variable. When creating a regression model, you should decide which variables will be the explained variable and which will be the explanatory one. The regression model describing the dependence of variables takes the form:

f competitiveness TOPSIS $=\Sigma$ (financial situation TOPSIS , EU funds, local taxes and fees, income from PIT and CIT, transfer income, operating surplus, debt, capital expenditure, current expenditure)

The results of the analysis show that the presented regression model explains $\mathrm{R}=0.412709$ variable variations. The values of the statistics F (17.39263) and the corresponding level of probability $\mathrm{p}$ confirm the statistical significance of the linear model. They also confirm that the parameters significantly differ from zero. The value of t-Student statistics at the parameter means that all parameters are statistically significant. The value of the determination coefficient $(\mathrm{R} 2=0.388980)$ indicates the fit of the regression model to the data (Table 4).

\section{Conclusion}

The analysis of spatial data requires a multi-criteria approach, requires knowledge of the degree and specificity of the diversity in space of the features of individual municipalities. Local objects are linked together in a dependency network. Knowledge and understanding of space structures enable better anticipation of changes and facilitate decisionmaking. The complex nature of municipalities means that its assessment requires the use of measures that comprehensively describe it (economic, financial, infrastructural, environmental, competitiveness, etc.).

The financial situation, as well as the competitiveness of communes, are a complex phenomenon and difficult to assess explicitly and objectively. The problem with assessing the operation of municipalities is the relatively large amount of information that creates information noise. This is due to relatively limited access to detailed and homogeneous data delimited at the municipal level. Factors of the financial situation and local competitiveness are not immutable in time, which is why they should be subject to continuous and ongoing analysis. 
Table 4

KMNK estimation (observations 1-207 used; dependent variable: TOPSIS competitiveness)

\begin{tabular}{|c|c|c|c|c|c|c|c|}
\hline & \multicolumn{2}{|c|}{ Rate } & \multicolumn{2}{|c|}{ standard error } & Student's t- & p-value & \\
\hline constant & \multicolumn{2}{|c|}{2.19899} & \multicolumn{2}{|c|}{1.00943} & 2.1784 & 0.03055 & ** \\
\hline EU funds & \multicolumn{2}{|c|}{$2.85789 \mathrm{e}-05$} & \multicolumn{2}{|c|}{$1.16367 \mathrm{e}-05$} & 2.4559 & 0.01491 & ** \\
\hline local charges and taxes & \multicolumn{2}{|c|}{0.171533} & \multicolumn{2}{|c|}{0.0882814} & 1.9430 & 0.05343 & * \\
\hline income from PIT and CIT & \multicolumn{2}{|c|}{0.62545} & \multicolumn{2}{|c|}{0.0926374} & 6.7516 & $<0.00001$ & *** \\
\hline transfer income & \multicolumn{2}{|c|}{0.137251} & \multicolumn{2}{|c|}{0.0790459} & 1.7363 & 0.08406 & * \\
\hline operating surplus & \multicolumn{2}{|c|}{0.18128} & \multicolumn{2}{|c|}{0.0465348} & 3.8956 & 0.00013 & $* * *$ \\
\hline indebtedness & \multicolumn{2}{|c|}{$1.13349 \mathrm{e}-05$} & \multicolumn{2}{|c|}{$3.29558 \mathrm{e}-06$} & 3.4394 & 0.00071 & $* * *$ \\
\hline capital expenditure & \multicolumn{2}{|c|}{-1.99473} & \multicolumn{2}{|c|}{1.00475} & -1.9853 & 0.04849 & ** \\
\hline current expenditure & \multicolumn{2}{|c|}{-1.98683} & \multicolumn{2}{|c|}{1.00365} & -1.9796 & 0.04913 & ** \\
\hline \multicolumn{2}{|c|}{ Arithmetic mean of the dependent variable } & \multicolumn{2}{|c|}{0.424203} & \multicolumn{3}{|c|}{ Standard deviation of the dependent variable } & 0.032861 \\
\hline \multicolumn{2}{|l|}{ Sum of squared residues } & \multicolumn{2}{|c|}{0.130639} & \multicolumn{3}{|c|}{ Residual Standard Error } & 0.025686 \\
\hline \multicolumn{2}{|c|}{ Co. determination (R-squared) } & \multicolumn{2}{|c|}{0.412709} & \multicolumn{3}{|c|}{ Corrected R-squared } & 0.388980 \\
\hline \multicolumn{2}{|l|}{$\mathrm{F}(8,198)$} & \multicolumn{2}{|c|}{17.39263} & \multicolumn{3}{|c|}{ P-value for the F test } & $1.65-19$ \\
\hline \multicolumn{2}{|l|}{ Logarithm of credibility } & \multicolumn{2}{|c|}{468.8714} & \multicolumn{3}{|c|}{ Akaike inform. crit. } & -919.7427 \\
\hline \multicolumn{2}{|l|}{ Crit. Bayes. Schwarz } & \multicolumn{2}{|c|}{-889.7483} & Cri & -Quinn & & -907.6132 \\
\hline
\end{tabular}

Source: own study based on data from RIO o / Kielce and BDL CSO

The value of the synthetic measure allowed dividing the communes of the Świętokrzyskie Province into 4 groups. Small groups in time and space can be observed between the groups. In 2017, the synthetic measure of the financial situation ranged from 0.30 (Bliżyn) to 0.51 (Sitkówka-Nowiny) and in 2007 from 0.31 (Pierzchnica) to 0.47 (Sitkówka-Nowiny). The synthetic measure of competitiveness in 2017 ranged from 0.37 (Moskorzew) to 0.51 (Masłów). In 2007, from 0.35 (Bejsce) to 0.48 (Sitkówka-Nowiny, Miedziana Góra), respectively. The best units in the studied area are located in the central part of the voivodship, in the area of impact of Kielce (the capital of the region); they have a developed industrial function (mining and processing of mineral raw materials, production of food products) and tourism.

The greatest impact on the level of the financial situation of rural communes in the Świętokrzyskie voivodship had: own revenues, from local taxes and fees, transfer, operating surplus and property (investment) and current expenses. In the analysed period, the level of competitiveness was affected by: income from PIT and CIT, as well as transfer, as well as the number of entities entered into the register and the number of natural persons conducting business activity. The analysed period of 2007-2017 was characterized by stable diversification of the financial situation of municipalities and their competitiveness.

\section{References:}

Churski, P., Borowczak, A., Dolata, M., Dominik, J., Hauke, J., Perdał, R., \& Konecka-Szydłowska, B. (2013). Czynniki rozwoju obszarów wzrostu i obszarów stagnacji gospodarczej w Polsce, Uniwersytet im. Adama Mickiewicza, Poznań.

Douglas, J.W., \& Gaddie, R.K. (2002). State rainy day funds and fiscal crises: Rainy day funds and the 1990-1991 recession revisited. Public Budgeting \& Finance, vol. 22. doi: 10.1111/1540-5850.00063

Dylewski, M., Filipiak, B., \& Szewczyk, A. (2004). Finanse publiczne. Instrumenty, struktury, procesy, FNUS, Szczecin, p. 74.

Dziekański, P. (2016). Spatial Differentiation of the Financial Condition of the Świętokrzyskie Voivodship Counties. Barometr Regionalny, Tom 14, nr 3.

Dziekański, P. (2014). Koncepcja wskaźnika syntetycznego do oceny sytuacji finansowej powiatów. Prace Naukowe Uniwersytetu Ekonomicznego we Wrocławiu, nr 329, pp. 98-108.

Dziekański, P. (2014). Analiza zróżnicowania kondycji finansowej powiatów województwa świętokrzyskiego. Nierówności Społeczne a Wzrost Gospodarczy, nr 40(4), pp. 42-54.

Dziekański, P. (2017). Diversification synthetic indicator for evaluating the financial capacity of local government. The case of polish voivodeships, Acta Universitatis Agriculturae Et Silviculturae Mendelianae Brunensis, vol.65, no. 2.

Dziekański, P., \& Pawlik, A. (2019). Intraregional diversification of the level of the financial situation of the poviats of Eastern Poland in relation to the development potential. Baltic Journal of Economic Studies, vol. 5, no. 3, pp. 1-8. doi: 10.30525/2256-0742/2019-5-3-1-8

Dziekański, P., \& Wyszkowski, A. (2018). Ocena przestrzennego zróżnicowania sytuacji finansowej gmin województwa świętokrzyskiego z wykorzystaniem miary syntetycznej. Optimum. Economic Studies, nr 1(91), pp. 219-238. 
Głowicka-Wołoszyn, R., \& Wysocki, F. (2016). Kondycja finansowa gmin wiejskich a źródła ich dochodów w województwie wielkopolskim. Roczniki Naukowe SERiA, tom XVIII, zeszyt 1.

Hendrick, R. (2004). Assessing and measuring the fiscal heath of local governments. Urban Affaires Review, vol. 40, no. 1. doi: $10.1177 / 1078087404268076$

Hwang, C.L., \& Yoon, K. (1981). Multiple attribute decision making. Methods and applications, Springer, Berlin [for:] A. Bieniasz, Z. Gołaś, A. Łuczak, 2013, Zróżnicowanie kondycji finansowej gospodarstw rolnych wyspecjalizowanych w chowie owiec i kóz w krajach Unii Europejskiej, Roczniki Ekonomii Rolnictwa I Rozwoju Obszarów Wiejskich, T. 100, z. 1.

Jóźwiak, M.A., Jóźwiak, M., \& Strzyż, M. (2010). Predyspozycje naturalne regionu świętokrzyskiego do rozwoju turystyki, Krajobraz a Turystyka, Prace Komisji Krajobrazu Kulturowego Nr 14, Komisja Krajobrazu Kulturowego PTG, Sosnowiec.

Klasik, A., \& Kuźnik, F. (2001). Konkurencyjny rozwój regionów w Europie, [In:] Konkurencyjność miast i regionów, ed. Z. Szymla. AE, Kraków, p. 2.

Kukuła, K. (2000). Metoda unitaryzacji zerowanej. PWN, Warszawa.

Łuczak, A., \& Wysocki, F. (2012). Zastosowanie uogólnionej miary odległości GDM oraz metody TOPSIS do oceny poziomu rozwoju społeczno-gospodarczego powiatów województwa wielkopolskiego. Przegląd Statystyczny Numer Specjalny 2.

Łuczak, J. (2007). Metody i techniki zarządzania jakością, Quality Progress, Poznań.

Majchrzak, A. (2012). Czynniki warunkujące kondycję finansową gmin województwa wielkopolskiego. Wydawnictwo Uniwersytetu Przyrodniczego, Poznań.

Malina, A. (2004). Wielowymiarowa analiza przestrzennego zróżnicowania struktury gospodarki Polski według województw. Wyd. Akademii Ekonomicznej w Krakowie, Kraków, pp. 96-97.

Marciniuk-Kluska, A. (2009). Konkurencyjność samorządu terytorialnego a finansowanie rozwoju lokalnego. Zeszyty Naukowe Akademii Podlaskiej w Siedlcach, nr 83, Seria: Administracja i Zarządzanie, p. 173.

Mercer, T., \& Gilbert, M. (1996). A financial condition index for Nova Scotia municipalities, Government Finance Review, vol. 12, No. 5. [for:] M. Stanny W. Strzelczyk, 2017, Pomiar kondycji finansowej jednostek samorządu lokalnego - kwerenda międzynarodowa. Nierówności Spoteczne a Wzrost Gospodarczy, nr 49 (1/2017).

Młodak, A. (2006). Analiza taksonomiczna w statystyce regionalnej. Centrum Doradztwa i Informacji, Difin, Warszawa. Ossowska, L., \& Ziemińska, A. (2010). Kondycja finansowa gmin wiejskich i miejsko-wiejskich województwa pomorskiego. Journal of Agribusiness and Rural Development, nr 4(18), s. 73-85, pp. 73-85.

Pawlik, A. (2012). Potencjał innowacyjny w rozwoju regionalnym. Uniwersytet Jana Kochanowskiego, Kielce, p. 147. Profil gospodarczy województwa świętokrzyskiego (2019). Retrieved from: https://www.wrota-swietokrzyskie. $\mathrm{pl}$ /gospodarka-regionu-swietokrzyskiego (accessed 15 July 2019).

Prus, P., \& Dziekański, P. (2019). Spatial diversification of the level of development and the financial situation of rural communes in the Świętokrzyskie Voivodeship. Annals of the Polish Association of Agricultural and Agribusiness Economists, vol. XXI, no. 1, pp. 74-82.

Raport o sytuacji społeczno-gospodarczej województwa świętokrzyskiego w 2017 r. (2018). Urząd Statystyczny w Kielcach, Kielce.

Satoła, Ł. (2015). Kondycja finansowa gmin w warunkach zmiennej koniunktury gospodarczej. Journal Agribusiness and Rural Development, $\mathrm{nr} 1(35)$, pp. 115-123.

Ślusarz, G. (2005). Studium społeczno-ekonomicznych uwarunkowań rozwoju obszarów wiejskich w świetle zagrożenia marginalizacją na przykładzie województwa podkarpackiego. Wydawnictwo Uniwersytetu Rzeszowskiego, Rzeszów.

Standar, A. (2017). Ocena kondycji finansowej gmin orazjej wybranych uwarunkowań na przykładzie województwa wielkopolskiego przy wykorzystaniu metody TOPSIS. Wieś $i$ Rolnictwo, nr 2(175).

Stanny, M. (2013). Przestrzenne zróżnicowanie rozwoju obszarów wiejskich w Polsce. IRWiR PAN, Warszawa.

Stanny, M., \& Strzelczyk, W. (2018). Kondycja finansowa samorządów lokalnych a rozwój społeczno-gospodarczy obszarów wiejskich, Ujęcie przestrzenne. IRWIR PAN, Warszawa.

Walesiak, M. (2011). Uogólniona miara odległości GDM w statystycznej analizie wielowymiarowej z wykorzystaniem programu R. Wyd. Uniwersytetu Ekonomicznego we Wrocławiu, Wrocław.

Wysocki, F. (2010). Metody taksonomiczne w rozpoznaniu typów ekonomicznych rolnictwa i obszarów wiejskich. Wydawnictwo Uniwersytetu Przyrodniczego w Poznaniu, Poznań.

Wysocki, F., \& Lira, J. (2005). Statystyka opisowa. Wyd. AR im. Augusta Cieszkowskiego w Poznaniu, Poznań.

Zakrzewska-Półtorak, A. (2011). Zasoby endogeniczne jako czynnik rozwoju lokalnego i regionalnego, Studium przypadków wybranych gmin województwa dolnośląskiego. Prace Naukowe Uniwersytetu Ekonomicznego we Wroctawiu, nr 152, pp. 579-588.

Zalewski, W. (2012). Zastosowanie metody TOPSIS do oceny kondycji finansowej spółek dystrybucyjnych energii elektrycznej. Ekonomia i Zarzadzanie, nr 4, pp. 137-145.

Żbikowski, J. (2015). Samorządy i organizacje pozarządowe jako beneficjenci procesu integracji europejskiej, handel wewnętrzny, nr 4(357), pp. 37-46. 